\title{
BEBERAPA ASPEK BIOLOGI KUTU PUTIH (Paracoccus marginatus) (HEMIPTERA: PSEUDOCOCCIDAE) PADA TERUNG DI RUMAH KACA
}

\author{
SOME ASPECTS BIOLOGICAL OF MEALYBUG (Paracoccus marginatus) \\ (HEMIPTERA: PSEUDOCOCCIDAE) IN EGGPLANT IN THE GREENHOUSE
}

\author{
Pratomi Simarmata*, Maryani Cyccu Tobing, Ameilia Zuliyanti Siregar \\ Jurusan Agroteknologi, Fakultas Pertanian Universitas Sumatera Utara, Medan, Indonesia \\ *Email: pratomisimarmata@gmail.com \\ * Corresponding Author, Diterima: 10 Des. 2020, Direvisi: 21 Mei. 2021, Disetujui: 22 Sep. 2021
}

\begin{abstract}
Eggplant (Solanum melongena) is a vegetable plant from the Solanaceae family that can be found growing in tropical and subtropical areas. P. marginatus is a polypagous pest that attacks eggplant. This study aims to study Several biological aspects of mealybug (P. marginatus) in eggplant. Research on the biology of white lice insects (Paracoccus marginatus) was carried out in greenhouses and plant pest laboratories, Faculty of Agriculture, University of Sumatra Utara using descriptive methods. The results showed that the life cycle of P. marginatus ranged between 31-37 (33,5 $\pm 5,18)$ days: eggs hatched after 6-8 (7.2 \pm 0.78) days, first instar nymph 5-7 (5.6 \pm 0.69$)$ days, instar nymph second male 5-6 (5.4 \pm 0.51$)$ days, second female instar nymph 4-5 (4.4 \pm 0.51$)$ days, third male instar nymph 3-4 (3.5 \pm 0.52$)$ days, third female instar nymph 4-5 (4.5 \pm 0.52$)$ days and male pupal 4-7 (4.7 \pm 0.94$)$. The ages of females were 1416 (14.7 \pm 0.67$)$ and males 3-5 (4.2 \pm 0.78$)$ days. During her lifetime, female imago can produce 1-2 ovisaks with a percentage of eggs that hatched $89.08 \%$. The ratio of male to female P. marginatus was 1: 2.67.
\end{abstract}

Keywords: Biological aspects of mealybug, eggplant, Paracoccus marginatus.

\begin{abstract}
ABSTRAK
Terung (Solanum melongena) merupakan tanaman sayur-sayuran dari famili Solanaceae yang dapat ditemukan tumbuh di daerah tropik maupun subtropik. P. marginatus merupakan hama polipag yang menyerang tanaman terung. Penelitian ini bertujuan untuk mempelajari beberapa aspek biologi kutu putih (P. marginatus) pada tanaman terung. Penelitian biologi serangga kutu putih (Paracoccus marginatus) dilaksanakan di rumah kaca dan laboratorium Hama Tumbuhan, Fakultas Pertanian, Universitas Sumatera Utara menggunakan metode deskriptif. Hasil penelitian menunjukkan bahwa: telur menetas setelah 6-8 (7.2 \pm 0.78$)$ hari, nimfa instar pertama 5-7 (5.6 \pm 0.69$)$ hari, nimfa instar kedua jantan 5-6 (5.4 \pm 0.51$)$ hari, nimfa instar kedua betina 4-5 (4.4 \pm 0.51$)$ hari, nimfa instar ketiga jantan 3-4 (3.5 \pm 0.52$)$ hari, nimfa instar ketiga betina 4-5 (4.5 \pm 0.52$)$ hari dan pupa jantan 4-7 (4.7 \pm 0.94$)$ hari. Siklus hidup P. marginatus berkisar antara 31-37 (33,5 $\pm 5,18)$ hari. Umur imago betina 14-16 (14.7 \pm 0.67$)$ dan imago jantan 3-5 (4.2 \pm 0.78$)$ hari. Imago betina selama hidupnya dapat menghasilkan 1-2 ovisak dengan presentase telur yang menetas $89.08 \%$. Perbandingan nisbah kelamin $P$. marginatus jantan: betina adalah $1: 2.67$.
\end{abstract}

Kata kunci : Biologi, Paracoccus marginatus, terung. 


\section{PENDAHULUAN}

Kutu putih papaya Paracoccus marginatus (Hemiptera : Pseudococcidae) ditemukan untuk pertama kalinya dari tanaman singkong Manihot esculenta di Meksiko pada tahun 1955. Hama ini dikumpulkan dari berbagai daerah di wilayah neotropis (Belize, Kosta Rika, Guatemala, dll). Williams dan Granara de Willink mendeskripsikan spesies pada tahun 1992 dan dideskripsikan kembali oleh Miller dan Miller pada tahun 2002 (Miller et al., 1999 ; Miller dan Miller, 2002 ).

Pada tahun 2002 di Guam, hama kutu putih $P$. marginatus dilaporkan menyerang tanaman pepaya dan kemudian pada tahun 2003 di Palau. Pada tahun 2004 hama ini menginvasi sampai Hawaii yang menyebabkan kerugian besar pada perkebunan pepaya (Heu et al., 2007).

Di Indonesia hama ini diketahui pertama kali menyerang tanaman papaya di Kebun Raya Bogor, Jawa Barat pada Mei dan Juli 2008 dilaporkan telah banyak merusak pertanaman papaya milik petani di Bogor. Selanjutnya, pada tahun 2009 P. marginatus dilaporkan menyerang lebih dari 21 spesies tanaman dari famili Apocynaceae, Araceae, Caricaceae, Convolvulaceae, Cucurbitaceae, Euphorbiaceae, Fabaceae, Malvaceae, Moraceae, Myrtaceae, Rubiaceae, Anacardiaceae, Rosaceae, Rutaceae, Sapindaceae, Sapotaceae, dan Solanaceae (Sartiami et al., 2009 ; Thalib et al., 2014).

Serangan hama kutu putih meluas dengan cepat ke berbagai wilayah Indonesia, antara lain Kabupaten Bogor, Sukabumi, Cianjur, Kota Depok (Jawa Barat), DKI Jakarta, Kabupaten Tangerang (Banten), beberapa kabupaten di Jawa Tengah, Kota Surabaya (Jawa Timur), Kota Pekanbaru (Riau), Denpasar(Bali), dan Sulawesi (Friamsa 2009; Muniappan 2011).

Masuknya hama P. marginatus ke Indonesia telah menimbulkan kerugian besar pada tanaman pepaya. Pada tahun 2009, 10 kabupaten sentra pepaya di Jawa Tengah (Sartiami et al., 2009).Terung (Solanum melongena) merupakan tanaman sayursayuran dari famili Solanaceae yang dapat ditemukan tumbuh di daerah tropik maupun subtropic yang merupakan tanaman inang dari hama kutu putih (Miller dan Miller, 2002; Hasyim et al., 2016)

Berdasarkan permasalahan di atas maka penulis tertarik untuk melakukan penelitian tentang beberapa aspek biologi kutu putih P. marginatus pada tanaman terung di rumah kaca untuk melengkapi data tentang biologi yang sangat dibutuhkan dalam pengendalian.

\section{BAHAN DAN METODE}

Penelitian ini dilaksanakan mulai Januari sampai Juni 2020 di Rumah Kaca dan Laboratorium Hama Tumbuhan, Fakultas Pertanian, Universitas Sumatera Utara, Medan. ( $\pm 25 \mathrm{~m}$ di atas permukaan laut) dengan suhu ruangan 23,95-33,60ÚC dan kelembaban relatif $54,60-84,00 \%$

Penelitian dilaksanakan dengan menggunakan metode deskriptif yaitu mengamati secara langsung siklus hidup P. marginatus yang dipelihara pada tanaman terung dalam kurungan di rumah kaca.

Benih terung S. melongena yang digunakan dalam penelitian ditanam langsung dalam polibagukuran $5 \mathrm{~kg}$ dalam satu lubang dengan kurungan serangga 
berbentuk kubus yang terbuat dari kayu dengan ukuran tinggi $40 \mathrm{~cm}$ dan lebar $50 \mathrm{~cm}$ yang ditutup dengan kain dengan tanaman terung sebanyak 10 ulangan. Imago generasi kedua yang dihasilkan, digunakan sebagai serangga uji dan ditutup dengan kain kasa. Setelah telur menetas diambil 10 ekor nimfa instar dan dipindahkan ke daun yang lain pada tanaman yang sama dengan mengunakan kuas halus.Media tanam harus dilakukan penyiraman secara teratur, untuk menjaga kelembabannya dan tanaman inang agar tidak kekuranan air.

Pengamatan untuk melihat stadia telur, nimfa dan imago P. marginatus dilakukan setiap hari meliputi warna dan umur setiap stadia. nimfa instar 1 dipelihara sampai menjadi imago untuk mengetahui lama stadia nimfa termasuk umur setiap nimfa instar dan jumlah nimfa yang menjadi imago.

Pengamatan untuk melihat jumlah ovisak $P$. marginatus hasil biakan pada tanaman terung. Ovisak (kumpulan telur) yang di hasilkan oleh satu pasang imago jantan dan betina.

Pengamatan ini dilakukan untuk melihat jumlah telur yang menetas dan yang tidak menetas.

$$
A=\frac{a}{a+b} \times 100
$$

\section{Keterangan :}

$\mathrm{A}=$ Presentase Telur menetas

$\mathrm{a}=$ Telur yang menetas

$\mathrm{b}=$ Telur yang tidak menetas

Pengamatan terhadap nisbah kelamin dinyatakan dalam perbandingan antara banyaknya jantan dan betina. Untuk membedakan imago jantan dan betina dapat dilihat dari warna tubuhnya. Individu betina memiliki warna tubuh kuning individu jantan memiliki tubuh yang berwarna merah muda.

\section{HASIL DAN PEMBAHASAN}

Stadia Telur, Nimfa dan Imago $P$. marginatus.

Hasil pengamatan terhadap $P$. marginatus yang dibiakan pada tanaman terung bahwa serangga ini mempunyai metamorfosis yang berbeda antara jantan dan betina. Serangga betina mengalami metamorphosis tidak sempurna (paurometabola) sedangkan serangga jantan mengalami metamorfosis sempurna (holometabola) (Gambar 1).

Telur diletakkan secara berkelompok dalam sebuah kantung (ovisak) di bagian bawah permukaan tanaman. Telur P. marginatus berbentuk oval berwarna kuning dan ditutupi oleh benang benang lillin seperti kapas (Gambar 2a) dan permukaan telur yang licin sedangkan telur yang tidak menetas bewarna kehitaman (Gambar 2b). Telur diletakkan di bagian bawah daun yang sejajar dengan tangkai dan tulang daun. Masa inkubasi telur sekiatar $6-8$ hari ( rata - rata $7.2 \pm 0.78$ hari).

Hasil penelitian ini tidak berbeda dengan yang dinyatakan oleh Suganthy et al. (2012) bahwa telur P. marginatus bening, berbentuk lonjong, dan berwarna kuning kehijauan. Telur dikumpulkan dalam ovisak disisi perut kutu putih betina dewasa dan diletakan dibawah daun. Periode inkubasi kutu putih P. marginatus padabunga matahari di bawah kondisi rumah kaca dan laboratorium (rata - rata 6,3 $\pm 0,58$ hari ) dan (rata - rata 7,20 $\pm 1,30$ hari).

\section{Nimfa}

Nimfa instar 1 yang baru keluar dari telur, bewarna putih kekuningan dan aktif bergerak mencari 


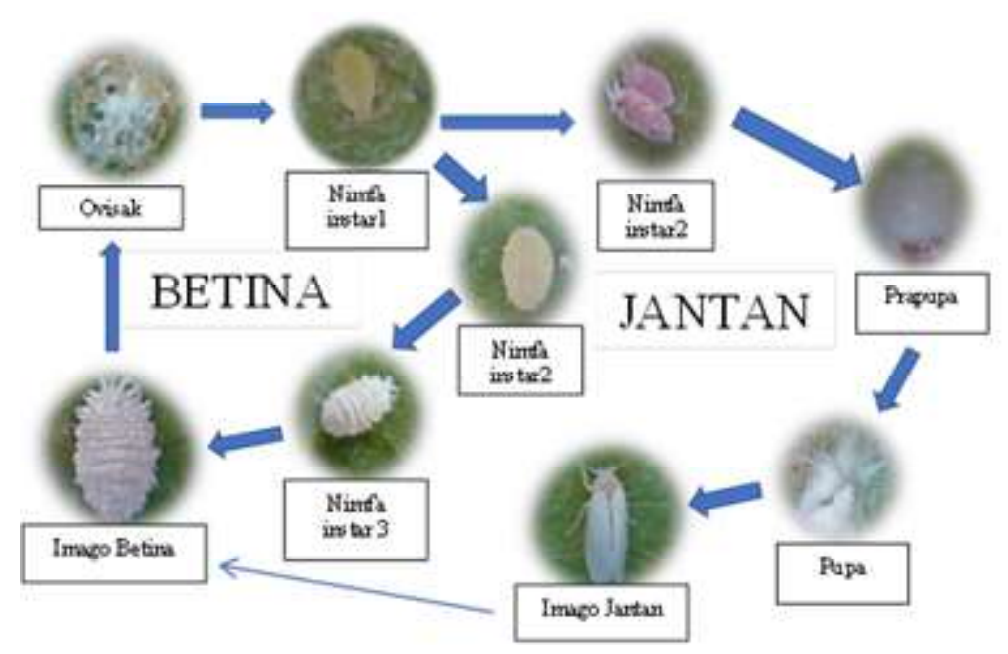

Gambar 1. Siklus hidup P. marginatus
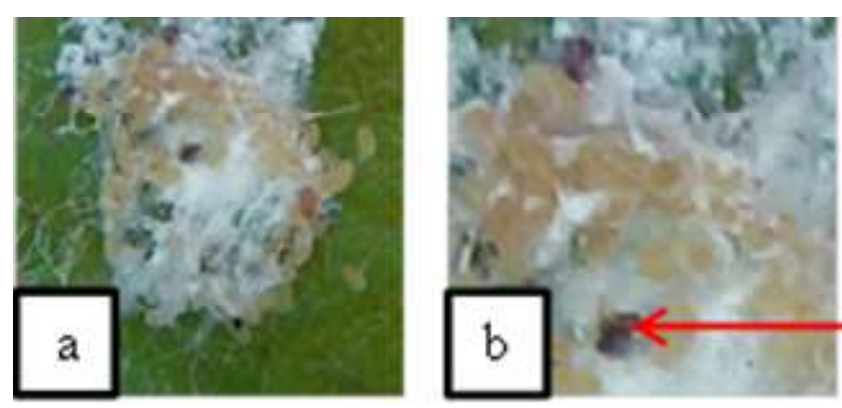

Gambar 2. (a) Kumpulan telur (b) Telur tidak menetas

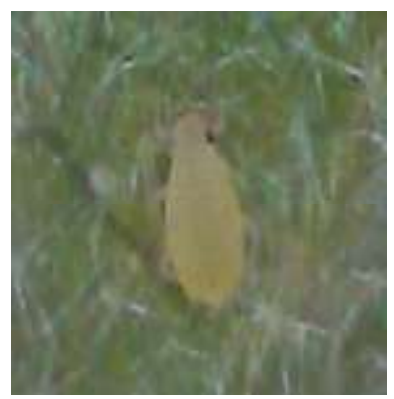

Gambar 3. Nimfa instar 1

tempat makanan disekitar tulang daun dan tunas muda, kemudian. Nimfa instar 1 antara jantan dan betina kutu putih P. marginatus belum dapat dibedakan. Lamanya hidup instar 1 sekitar 5-7 hari ( rata - rata 5.6 \pm 0.69 hari ) (Gambar 3).

Seperti yang di nyatakan ol eh A marasekare et al. (2008a) bahwa pada stadium nimfa instar 1 jenis kelamin antara jantan dan betina belum dapat dibedakan. Perbedaan antara jantan dan betina dapat dilihat ketika serangga memasuki nimfa instar 2 . Lamanya hidup nimfa instar 1 di antara tanaman inang parthenium dan plumeria, instar pertama pada plumeria menunjukkan durasi tertinggi (rata-rata 6,6 $\pm 0,1$ hari) dan parthenium menunjukkan durasi terendah (ratarata 5,8 $\pm 0,1$ hari ), Pramayudi dan Oktarina (2012) menyatakan bahwa nimfa instar satu pada tanaman pepaya berlangsung selama (rata-rata $4,4 \pm 1,07$ hari).

Nimfa instar 2 yang baru berganti kutikula berwarna putih kekuningan, kemudian berubah menjadi kemerahan. Perbedaan antara nimfa jantan dan betina sudah dapat dilihat dengan berdasarkan warna tubuhnya. Nimfa jantan memiliki tubuh berwarna kemerahan (Gambar 4a) sedangkan nimfa betina berwarna kekuningan (Gambar 4b). Nimfa instar 2 tidak seaktif instar pertama. Lama hidup nimfa instar betina sekitar $4-5$ hari (rata - rata $5.4 \pm 0.51$ hari) dan nimfa jantan sekitar 5-6 hari (rata- rata $4.4 \pm 0.51$ hari). Seperti yang dinyatakan oleh Chellappan et al. (2013) bahwa nimfa instar kutu putih kedua sudah 
dapat dibedakan jenis kelaminnya dengan melihat warna tubuhnya. Nimfa instar dua jantan tubuhnya berwarna merah muda, sedangkan yang betina berwarna berwarna kuning, Husni et al. (2012) menyatakan bahwa lama hidup nimfa instar 2 betina pada tanaman ubi kayu (rata - rata $5.5 \pm 0.84$ hari) dan nimfa 2 jantan (rata rata $5.3 \pm 0.50$ hari), dan Maharani et al. (2016) menyatakan bahwa lama hidup nimfa instar 2 betina pada tanaman jarak pagar (rata - rata 5,90 $\pm 0,30$ hari) dan nimfa instar 2 jantan (rata-rata 5,57 $\pm 0,25$ hari ).

Nimfa jantan instar 3 ini ukuran tubuhnya lebih ramping dari pada betina dan mempunyai satu tahapan perkembangan lagi sebelum menjadi imago yaitu stadium pupa dan lamanya hidup berkisar 3-4 hari (rata - rata $3.5 \pm 0.52$ hari) (Gambar 5b) sedangkan nimfa instar 3 betina tahap perkembangan ini merupakan tahap perkembangan akhir yang tidak mengalamai stadium pupa sebelum menjadi imago dan lamanya hidup berkisar $4-5$ hari (rata - rata $4.5 \pm$ 0.52 hari) (Gambar 5a).

Seperti yang dinyatakan oleh Suganthy et al. (2012) bahwa nimfa instar ketiga betina ukuran tubuhnya lebih besar dibandingkan dengan yang jantan. Stadia nimfa instar ketiga pada jantan disebut pra-pupa, dan sekitar tubuh serangga jantan mulai diselimuti oleh benang-benang lilin. Lama hidup nimfa instar 3 betina pada bunga matahari di bawah kondisi rumah kaca dan laboratorium ( rata - rata 5,00 $\pm 1,00$ hari) dan nimfa instar 3 jantan ( rata - rata 4,80 $\pm 0,45$ hari).

Pupa hanya terjadi pada individu jantan yang ditutupi lapisan lilin yang bewarna keputihan yang terdapat dipermukaan daun dan lama hidup sekitar 4 -7 hari (rata - rata $4.7 \pm 0.94$ hari) (Gambar 6) .
Seperti yang dinyatakan oleh Illathur et al. (2018) menyatakan bahwa nimfa instar 4 atau pupa hanya dimiliki jantan yang ditutupi benang-benang lilin tanpa rumah pupa atau kokon. Lamanya hidup tahap pupa berkisar antara 3,00 - 3,25 hari dengan (rata rata $2,92 \pm 0,38$ hari).

\section{Imago}

Imago betina tubuhnya berbentuk oval berwarna kuning yang ditutupi oleh lapisan lilin berwarna putih yang tebal dengan tidak bersayap dan
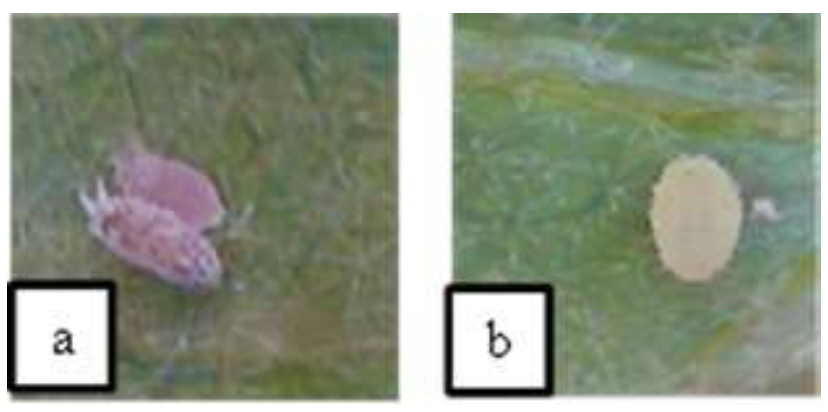

Gamabar 4. (a) Nimfa instar 2 jantan (b) Nimfa instar 2 betina.
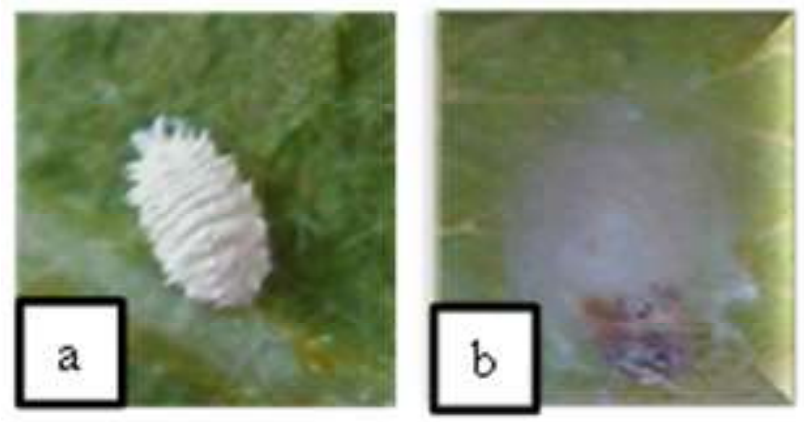

Gambar 5. (a) Nimfa instar 3 betina (b) pra pupa jantan

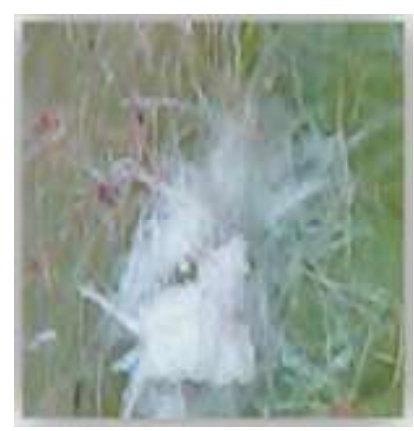

Gambar 6. Pupa jantan 
lama hidup berkisar 14 - 16 hari (rata - rata $14.7 \pm$ 0.67 hari)(Gambar 7a) sedangkan imago jantan bewarna merah muda kekuningan dan memiliki sepasang sayap serta aktif terbang dan lama hidup berkisar 3 - 5 hari ( rata - rata $4.2 \pm 0.78$ hari) (Gambar 7b).

Yani et al. (2016) menyatakan bahwa imago betina memiliki permukaan tubuh yang dilapisi oleh lilin putih tipis, memiliki rangkaian filamen lilin di sekitar tepi tubuh bagian posterior panjang tubuhnya dan tidak memiliki sayap imago jantan memiliki antenna dan sayap berkembang dengan baik. Lamanya hidup imago jantan dan betina pada tanaman papaya (rata - rata 2,74 \pm 0,17 hari) dan (rata - rata 14,93 $\pm 1,75$ hari), jarak pagar (rata - rata 2,85 $\pm 0,15$ hari) dan (rata - rata $13,67 \pm 1,74$ hari).

Hasil penelitian ini menunjukkan bahwa siklus hidup P. marginatus jantan dan betina pada tanaman terung berkisar antara 31-37 (rata - rata 33,5 $\pm 5,18$ hari) hari, berbeda dengan penelitian yang dilakukan Perbedaan ini diduga karena tanaman inang yang berbeda. Jithu et al. (2016) menyatakan bahwa setiap tanaman inang memiliki kualitas nutrisi, antibiosis dan unsur pokok kimia lainya yang berbeda sehingga dapat mempengaruhi lamanya siklus hidup serangga kutu putih.

\section{Jumlah ovisak dari sepasang imago $P$. marginatus.}

Dari tabel 1 diperoleh bahwa jumlah ovisak atau kumpulan telur yang dihasilkan dari satu pasang imago P. marginatus pada tanaman terung berkisar 1 - 2 ovisak atau kumpulan telur dengan rata - rata 1,6 ovisak. CABI/EPPO, (2012) menyatakan bahwa ovisak yang dihasilkan oleh seekor imago $P$. marginatus pada tanaman kentang sebanyak 2-3 ovisak. Demikian pula Al-Helal et al. (2012) juga menyatakan bahwa ovisak yang dihasilkan imago P. marginatus pada tanaman papaya berkisar 3-4 ovisak. Amaresekare et al. (2008b) menyatakan bahwa tanaman inang yang berbeda menyediakan kualitas nutrisi, unsur pokok. kimia yang berbeda, sehingga hal ini dapat memepengaruhi karakteristik suatu populasi terutama tingkat perkembangan, tingkat reproduksi, dan ketahanan serangga. Perbedaan hidup P. marginatus pada beberapa tanaman inang dapat dapat disebabkan faktor nutrisi, dan struktur fisik tanaman inang.

\section{Persentase Telur menetas $P$. marginatus}

Hasil pengamatan terhadap persentase telur $P$. marginatus yang menetas pada suhu dapat dilihat pada Tabel 2 menunjukan bahwa persentase telur menetas tertinggi dengan $95.86 \%$ sedangkan yang terendah sekitar $76.64 \%$ dengan persentase rata-rata 89.08 \%. Yani et al. (2016) menyatakan bahwa persentase
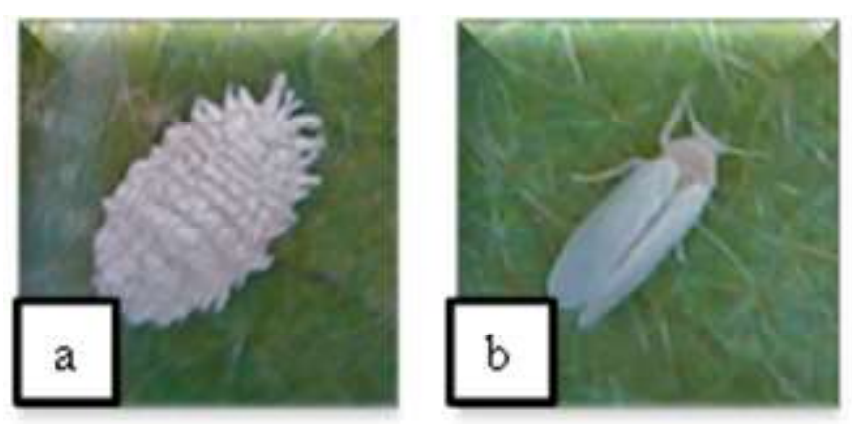

Gambar 7. (a) Imago betina (b) Imago jantan

Tabel 1. Jumlah ovisak dari sepasang imago P. marginatus

\begin{tabular}{cc}
\hline Ulangan & Jumlah Ovisak \\
\hline 1 & 1 \\
2 & 2 \\
3 & 1 \\
4 & 2 \\
5 & 2 \\
\hline Jumlah & 8 \\
\hline Rata- rata & 1.6 \\
\hline
\end{tabular}


Tabel 2. Persentase telur P. marginatus yang menetas.

\begin{tabular}{ccccc}
\hline Ulangan & $\begin{array}{c}\text { Jumlah telur } \\
\text { (1 Ovisak) }\end{array}$ & $\begin{array}{c}\text { Telur } \\
\text { Menetas }\end{array}$ & $\begin{array}{c}\text { Telur tidak } \\
\text { menetas }\end{array}$ & $\begin{array}{c}\text { Persentase telur } \\
\text { menetas (\%) }\end{array}$ \\
\hline 1 & 197 & 151 & 46 & 76.64 \\
2 & 220 & 206 & 14 & 93.63 \\
3 & 175 & 155 & 20 & 88.57 \\
4 & 290 & 278 & 12 & 95.86 \\
5 & 215 & 195 & 20 & 90.69 \\
\hline Jumlah & 1050 & 949 & 101 & 445.41 \\
\hline Rata - rata & 210 & 189.8 & 20.2 & 89.08 \\
\hline
\end{tabular}

Tabel 3. Nisbah kelamin P. marginatus.

\begin{tabular}{cccc}
\hline \multirow{2}{*}{ Ulangan } & \multicolumn{2}{c}{ Jumlah imago P. marginatus } & \multirow{2}{*}{ Nisbah Kelamin } \\
\cline { 2 - 3 } & Jantan & Betina & $1: 2.77$ \\
2 & 40 & 111 & $1: 3.79$ \\
3 & 43 & 163 & $1: 3.18$ \\
4 & 37 & 118 & $1: 2.23$ \\
5 & 86 & 192 & $1: 2.14$ \\
\hline Jumlah & 62 & 133 & \\
\hline Rata - rata & 268 & 717 & \\
\hline
\end{tabular}

telur yang menetas paling tinggi terjadi pada tanaman pepaya $(93,9 \%)$, jarak pagar $(92,9 \%)$, dan ubi kayu (75,5\%). Jithu et al. (2016) menyatakan bahwa peluang telur untuk menetas $80-90 \%$ dalam kisaran suhu $20^{\circ} \mathrm{C}$ dan $30^{\circ} \mathrm{C}$. Sementara suhu di rumah kaca berkisar dan kelembaban relatif berkisar 23,95 33,60ÚC (rata - rata 30,79úC \pm 1.93 ).

\section{Nisbah Kelamin P. marginatus}

Hasil pengamatan nisbah kelamin P. marginatus pada Tabel 3 diperoleh bahwa jumlah serangga betina lebih banyak dari pada jantan dan rataan nisbah kelamin, yaitu 53.6 ekor jantan dan 143,4 ekor betina dengan ratio imago jantan dan betina $1: 2.67$. Seni dan Sahoo (2014) melakukan penelitian bilogi $P$. marginatus pada berbagai suhu. Pada suhu $8^{\circ} \mathrm{C}-23^{\circ} \mathrm{C}$ nisbah kelamin 1: 1.2 , pada suhu $17^{\circ} \mathrm{C}-28^{\circ} \mathrm{C}$ nisbah kelamin jantan:betina yaitu $1: 1.23$, pada suhu $15^{\circ} \mathrm{C}$ - $31^{\circ} \mathrm{C}$ nisbah kelamin $1: 2.07$. Semakin tinggi suhu, maka jumlah imago betina semakin tinggi pula. Sementara suhu di rumah kaca berkisar 23,95 33,60ÚC (rata - rata 30.79 ÚC \pm 1.93 ) sehingga perbandingan imago betina lebih tinggi dibandingkan imago jantan.

\section{KESIMPULAN}

Kesimpulan dari hasil penelitian ini yaitu telur menetas setelah 6-8 (7.2 \pm 0.78$)$ hari, nimfa instar pertama 5-7 (5.6 \pm 0.69$)$ hari, nimfa instar kedua jantan 5-6 (5.4 \pm 0.51$)$ hari, nimfa instar kedua betina 4-5 (4.4 \pm 0.51$)$ hari, nimfa instar ketiga jantan 3-4 (3.5 \pm 0.52$)$ hari, nimfa instar ketiga betina 4-5 (4.5 \pm 0.52$)$ hari, pupa jantan 4-7 (4.7 \pm 0.94$)$ hari, imago betina 14-16(14.7 \pm 0.67$)$ dan imago jantan 3$5(4.2 \pm 0.78)$ hari, Imago betina selama hidupnya dapat 
menghasilkan 1-2 ovisak dengan rataan 1.6 ovisak, Persentase telur menetas $P$. marginatus pada terung rata-rata mencapai $89.08 \%$, Perbandingan nisbah kelamin jantan betina P. marginatus adalah 1 : 2.6.

\section{UCAPAN TERIMA KASIH}

Ucapan terima kasih disampaikan kepada Ibu Prof. Dr. Dra Maryani C. Tobing, MS., dan Ameilia Zuliyanti Siregar, SSi, M.Sc, Ph.D atas ilmu serta saran dalam penyusunan jurnal.

\section{DAFTAR PUSTAKA}

.Miller DR, Williams DJ, \& Hamon AB. 1999. Notes on a new mealybug (Hemiptera: Coccoidea: Pseudococcidae) pest in Florida and the Caribbean: the papaya mealybug, Paracoccus marginatus Williams and Granara de Willink. Insecta Mundi 13(3-4): 179-181

Al-Helal MA, Ahmed KN, Khanom NEP, Bulbul S. 2012. Observation on Papaya Mealybug, Paracoccus marginatus Williams and Granara (Hemiptera: Pseudococcidae) damiging some crops in Bangladesh. Journal of Plant Protection sciences. 4(2):8-15.

Amarasekare KG, Chong JH, Epsky ND, Mannion CM. 2008a. Effect of temperature on the life history of the mealybug Paracoccus marginatus (Hemiptera: Pseudococcidae). $J$ Econ Entomol. 101: 1798-1804.

Amarasekare KG, Mannion CM, Osborne LS, Epsky ND. 2008b. Life history of Paracoccus marginatus (Hemiptera: Pseudococcidae) on four host plant species under laboratory conditions. Env Entomol. 37(3): 630-635.
CABI/EPPO. 2012. Paracoccus marginatus. Distribution Maps of Plant Pests, MapNo. 614. CAB International with EPPO. 2 p.

Chellappan M, Lawrence L, \& Ranjith MT. 2013. Biology and morphometry of Paracoccus marginatus Williams and Granara de Willink (Hemiptera: Pseudococcidae). Entomon. 38(2): 97-110.

Friamsa N. 2009. Biologi dan Statistik Demografi Kutu Putih Pepaya, Paracoccus marginatus Williams \& Granara de Willink (Hemiptera: Pseudococcidae) pada Tanaman Pepaya (Carica papaya L). Departemen Proteksi Tanaman, Institut Pertanian Bogor, Bogor.

Hasyim, A., W. Setiawati dan Liferdi. 2016. Kutu Kebul Bemisia tabaci Gennadius (Hemiptera: Aleyrodidae) Penyebar Penyakit Virus Mosaik Kuning pada Tanaman Terung. Iptek Hortikultura.

Heu RA, Fukada MT, Conant P. 2007. Papaya mealybug, Paracoccus marginatus Williams and Granara de Willink (Hemiptera: Pseudococ-cidae). State of Hawaii New Pest Advisory. Department of Agriculture No. 04-03 March 2007.

Husni, Pramayudi N, Faridah M. 2012. Biology of papaya mealy bug Paracoccus marginatus (Hemiptera: Pseudococcidae) in Cassava (Manihot utilissima pohl). Jurnal Natural . 12(2): 1-9.

Illathur R, Sridhar RP and Kennedy JS. 2018. Study on biology of Phenacoccus solenopsis (Tinsley) (Hemiptera: Pseudococcidae), Paracoccus marginatus (Williams and Granara de Willink) (Hemiptera: Pseudococcidae), Maconellicoccus hirsutus 
(green) (Pseudococcidae: Hemiptera) and Ferrisia virgata (Cockerell) (Hemiptera: Pseudococcidae) in laboratory conditions. Journal of Fauna and Biological 5(5): 27-31.

Jithu UK, Meera G, Ajesh G, Jithine JR, Lekshmi NR, Deepasree MI. 2016. Areview on Paracoccus marginatus Williams, papaya mealy bug (Hemiptera: Pseudococcidae). Journal of Entomology and Zoology 4(1): 528-533

Maharani, Y. A., Rauf, A., Sartimi, R., Anwar. 2016. Biologi dan neraca hayati kutu putih pepaya Paracoccus marginatus Williams and Granara de Willink (Hemiptera: Pseudococcidae). Institut Pertanian Bogor, Bogor.

Miller DR, Miller GL. 2002. Redescription of Paracoccus marginatus Williams, D. J. and Granara de Willink, (Homoptera: Coccoidea: Pseudococcidae), including descriptions of the immature stages and adult male. Proc Ent Soc Washington 104 (1): 1-23.

Muniappan R, Shepard BM, Watson GW, Carner GR, Rauf A, Sartiami D, Hidayat P, Afun JVK, Ziaur Rahman AKM. 2011, New records of invasive insects (Hemiptera: Sternorrhyncha) in Southeast Asia and West Africa. J Agric Urban Ent. 26: 167-174

Pramayudi, N dan H.Oktarina, 2012. Biologi hama kutu putih pepaya (Paracoccus marginatus) pada tanaman pepaya. Fakultas Pertanian,
Universitas Syiah Kuala Darussalam Banda Aceh. J. Floratek 7: $32-44$

Sartiami, D., Dadang, R. Anwar \& I.S. Harahap. 2009. Persebaran Hama Baru Paracoccus marginatus di Propinsi Jawa Barat (Abstrak). Di dalam: Buku Panduan Seminar Nasional Perlindungan Tanaman. Bogor.

Seni, A. and Sahoo, A. K. 2014. Biology of the papaya mealybug, Paracoccus marginatus Williams and Granara de Willink (Hemiptera : Pseudococcidae). IJAEB 7(4) : 875-81.

Suganthy, M., Janaki., I. and Sakthivel, P. 2012. Biology of Mealy Bugs, Paracoccus marginatus (Williams and Granara de Willink) and Phenacoccus solenopsis (Tinsley) on Sunflower under Greenhouse and Laboratory. Madras Agricultural Journal 99(4): 371-373.

Thalib, R. Fachrullah, R.R. Adam, T. Khodijah. Dan Herlinda, S. 2014. Populasi dan serangan kutu putih pepaya Paracoccus marginatus (Hemiptera: Pseudococcidae) pada tanaman pepaya di daerah dataran rendah Sumatera Selatan. J. HPT Tropika 14 (2): 136 - 141.

Yani M, Aunu R, Dewi S, dan Ruly A. 2016. Biologi dan neraca hayati kutu putih pepaya Paracoccus marginatus Williams \& Granara de Willink (Hemiptera: Pseudococcidae) pada tiga jenis tumbuhan inang. Bogor. J. HPT Tropika 1: $1-9$. 